\title{
Chance Operations and Randomizers in Avant-garde and Electronic Poetry

\author{
Tying Media to Language
}

Jonathan Baillebache

\begin{abstract}
This article explores and compares the use of chance procedures and randomizers in Dada, Surrealism, Russian Futurism, and contemporary electronic poetry. I analyze the role of materiality of media in creating unexpected literary outcomes through a discussion of Freud's concept of the uncanny and Katherine Hayles's concept of computation as symptom.
\end{abstract}

$\mathrm{T}_{\mathrm{H}}$ E GOAL OF THIS ESSAY IS TO COMPARE THE LITERARY USE OF chance operations by historical avant-garde poets (Dadaists, Russian Futurists, and Surrealists) with the use of randomness in electronic literature (specifically in generative poetry). In this essay, randomness and chance are essentially equivalent terms, but reflect different cultural and epistemological contexts. Chance is traditionally associated with art and print literature, such as automatic writing or the cut-up technique, whereas randomness in this essay is associated with computers and electronic literature. Literary uses of chance or randomness are context-bound and reflect different artistic agendas: in the surrealists' literary technique of automatic writing, ${ }^{1}$ for instance, randomness is used in order to explore the unconscious, whereas in Nanette Wylde's electronic poem Storyland, randomness is used to explore the ambiguity between human subjects and machines. How do these different contexts of bibliographic publication and protocols

1. André Breton and Philippe Soupault's Les Champs Magnétiques, published in France in 1920, is considered one of the first books written with the method of "automatic writing", or, as Breton puts it, "to blacken paper with a laudable disregard for any literary output" ["noircir du papier avec un louable mépris de ce qui pourrait en sortir littérairement" ]. See Breton 1996, 326. 
of creation transform our interpretation of the use of chance in literature? What does this comparison between different context-bound literary uses of randomness teach us about the role of bibliographic components in building our interpretation of literary texts? In this essay, I argue through the example of Russian futurist poetry and generative poetry that the distinction between mechanistic chance operations (whether physics-based or computational) and the kind of free-association displayed in automatic writing is not clear cut. A reevaluation of the concept of the unconscious in light of new forms of electronic uses of randomness could help us better understand the nature of subjectivity in contemporary electronic literature and offer the opportunity to read generative poetry in terms of its past.

Numerous examples show that randomness, a function built into most programming languages, is a prominent component of electronic literature. $^{2}$ It is startling, somehow exhilarating, and uncanny to play pieces of electronic literature that display randomness at the core of their aesthetic. One feels almost immersed in a world haunted by cybernetic ghosts. Generative poetry is the category of electronic literature that makes the most obvious use of randomness. Nanette Wylde's generative poem Storyland, for instance, published in the Electronic Literature Collection, generates random short poems by coupling sets of words according to a series of randomly obtained numbers against the soundtrack of an amusement park (Wy LDE 2006). One among many possible iterations of this generative poetry reads as follows:

Before the age of technology, an over-achiever believed in humanity. The over-achiever denied the truth.

The earth moved.

The over-achiever plagiarized the works of a super cool disc jockey. The super cool disc jockey also denied the truth but refused to admit anything.

While watching them, a hermaphrodite delighted others with silliness. The hermaphrodite was ruthless.

Deals were made.

2. Mark Sample presented a prehistory of literary use of randomness in computing in his talk "An Account of Randomness in Literary Computing" (http://www samplereality.com/2013/01/08/an-account-of-randomness-in-literary-com puting/). 
The hermaphrodite wanted to be the over-achiever. The over-achiever forgave the super-cool disc jockey.

When compared to earlier uses of chance operation in literature, a piece like this one resembles some of the automatic writings produced by André Breton and Philippe Soupault in their collective work The Magnetic Fields:

The bird in this cage makes the dedicated-to-blue pretty child cry. Her father is an explorer. The new-born kitties rotate. There are in those woods pale flowers that make those who pluck them die. The whole family is prosperous and gathers under this lime-tree after mealtime. ${ }^{3}$

The difference between Nanette Wylde's Storyland and Breton and Soupault's Magnetic Fields is that the former is produced according to a computational algorithm involving randomizers and user interaction, and the latter by two free-wheeling human subjects. But the resemblance between the two is uncanny, and part of Storyland's interest is to question, through its resemblance with surrealist writing, the assumed difference between the human mind and cybernetics. Generative poetry has indeed a tendency to present itself as a simulation of such or such print literature or writer.

One could argue that a piece like Storyland is the only one of the two that could claim to be randomly generated because it relies on computational randomizers, the computing equivalent of dice, whereas Magnetic Fields makes no use of any true mechanistic random device. We could indeed suspect that the Magnetic Fields' prose is determined by its authors' unconscious drives, and therefore is not random in the same sense that a text of generative poetry is randomized by the combination of an algorithm and the user's input. The intrusion of computational or mechanistic constraints between writers and literary outcomes could be thought to produce a purer form of randomness than the kind emerging from the unconscious. If we gave into this dichotomy, the sort of randomness that the Freudian unconscious produces, surprising in its formations yet determined by the return of the repressed, would be incomparable with the randomness that machines and chance operations produce. Indeed, it was precisely Breton's

3. "Loiseau dans cette cage fait pleurer la jolie enfant vouée au bleu. Son père est un explorateur. Les petits chats nouveau-nés tournent. Il y a dans ce bois des fleurs pâles qui font mourir ceux qui les cueillent. Toute la famille est prospère et se réunit sous ce tilleul après le repas." (Breton and Soupault 1971, 44). Unless otherwise indicated, all translations from French to English are my own. 
point to use automatic writing as a way to unveil and explore the Freudian unconscious, and a point of departure from the mechanistic chance operations proposed by Dada poets such as Tristan Tzara. ${ }^{4}$ Contemporary uses of randomizers in electronic literature would thus be closer to the Dadaist use of mechanical chance operations (like pulling out cut-up words from a shuffling $\mathrm{bag}^{5}$ ) than to surrealist automatic writing. A piece of electronic poetry like Jörg Piringer's applet Konsonant, for instance, demonstrates that Dadaist physics-based chance procedures such as shuffling words in a bag can be fully simulated by computers down to the very visual pleasure of seeing letters bounce on one another. ${ }^{6}$ If one were to distinguish computational random poetical engines from automatic writing, one could thus question the relevance of the Freudian unconscious to understand electronic literature, or, for that matter, the relevance of the Freudian unconscious to understand what Katherine Hayles calls the "Computational Universe"? Where, indeed, could we locate the unconscious of any authorial figure in Nanette Wylde's Storyland? The same questions apply to Dadaist poetry. Generative poetry epitomizes the crisis of authorial subjec-

4. Mark Sample comments this split between the mechanistic chance operation of Dada and the Surrealist use of automatic writing in his chapter on Randomness in Montfort 2012.

5. "Pour faire un poeme dadaiste : / Prenez un journal./ Prenez des ciseaux. / Choisissez dans ce journal un article ayant la longueur que vous comptez donner à votre poème. / Découpez l'article. / Découpez ensuite avec soin chacun des mots qui forment cet article et mettez-les dans un sac. / Agitez doucement. / Sortez ensuite chaque coupure l'une après l'autre dans l'ordre où elles ont quitté le sac. / Copiez consciencieusement. / Le poème vous ressemblera. / Et vous voilà un "écrivain infiniment original et d'une sensibilité charmante encore qu'incomprise du vulgaire" (Tzara 1920, 18) ["IN ORDER TO MAKE A DADAIST POEM: / Take a journal. / Take scissors. / Out of this journal pick an article of the length you want to give to your poem. / Cut up the article. / Then cut up accurately each of the words composing this article and put them in a bag. / Shuffle gently. / Take out next each cut-up word one after the other in the same order as they leave the bag. / Copy scrupulously. / The poem will resemble you. / And here you are, 'an immensely original writer with a charming sensibility, although misunderstood by the populace"].

6. See Piringer 2012.

7. Hayles addresses the connection between Jacques Lacan's reading of the Freudian unconscious and cybernetics but avoids using the word "unconscious" in her own critical apparatus when exploring electronic literature, preferring terms like "non-conscious" or "a-conscious" to describe the impact of machines on human subjectivity. See Hay les 2005. 
tivity initiated by Dada poetry by further pulling the author's agency away for the text through the use of readers' input, who must click on a 'New Story" round-shaped pink button in order to seed the computational randomizer's algorithm with new data.

However tempting, such a dichotomy between generative poetry's randomizing procedures and the unconscious nature of automatic writing obscures the fact that generative poetry does not merely simulate the physics of Dadaist poetry or the randomizing of its content, but also, and more importantly, its poetical language. Whoever tried to instantiate Tzara's instructions POUR FAIRE UN POEME DADISTE by cutting up words in a periodical and shuffling them in a bag would realize that randomization of content is only one of the tricks of Dadaist poetry. In parallel to randomization of content, the resulting heteroclite typography of such a Dadaist poem will play an important part in the poem's signifying strategies. Dadaist poetry questions the authorial subjectivity of literature from the point of view of the materiality of literature. The materiality of Dadaist poetry is indeed addressed by Nanette Wylde through the use of color fonts and circus music in Storyland. Likewise, Breton and Soupault, despite their political dispute with Tzara, acknowledge their Dadaist inspiration when they describe automatic writing as relying on the materiality of media "to blacken paper" (BRETON 1996, 326). ${ }^{8}$

It would certainly be a limitation to interpret automatic writing exclusively through the Surrealists' programmatic agenda of unveiling their author's unconscious, or, for that matter, some sort of collective unconscious pertaining to both authors and readers. Unless we support the fiction of a collective unconscious, automatic writings' psychoanalytical value is limited by the fact that literary text's meaning is co-constructed by a collectivity of readership and cannot speak only for and from its original authors. Earlier examples of automatic writing produced by Russian Futurists show that automatic writings' meaning is negotiated with readers in conjunction with the materiality emerging from the media of literature itself. Artists' books created by the Russian futurist poets in the 1910s and early 1920s combine

8. In a gesture identified by Friedrich A. Kittler, surrealist writers, like their Dadaist counterparts, create a shortcut between literature and madness by fully identifying with the media of literature, turning paper into a mode of being distinguishing literature from psychoanalysis. See KITTLER 1999. 
both the Dadaist mechanical approach to randomness and the Surrealists' interest in the unconscious. Russian Futurist poets such as Aleksej Kručenyh, Ilja Zdanevič, Velimir Hlebnikov, or Roman Jakobson all contributed to a collective poetical experiment known as "zaum language", or the language "beyond reason". Their program was to create a poetry illustrating a would-be universal poetical language made up of pseudo-words whose signification remains undetermined. In a poem like Kručenyh's Dyr bul shchyl,${ }^{9}$ for instance, words are not based on familiar roots and prefixes of Russian, but seem to be created totally randomly, although according, mostly, to Russian morphology:

\author{
3 poems \\ written in \\ their own language \\ it differs from oth.: \\ its words have no \\ definite meaning \\ No.1.Dyr bul shchyl \\ ubeshshchur \\ skum \\ vy so bu \\ r 1 ez \\ (KRUČENYH 1913)
}

The reader stands at a loss in front of such a text and deeply feels that his or her interpretations can only be random. Furthermore, some words can be deciphered using the morphology of different languages. If the first word, "Dyr" resembles a Russian word (dyra: "a hole"), the third one, "shchyl", evokes the morphology of Ukrainian. Zaum language was indeed created to be a universal poetical language, a language that would mean differently according to the language you would read it with, on the basis of a universal grammar of instinctual drives correlated to certain sounds and letter shapes. More so than Dadaist poetry, zaum poetry intends to give randomness a positive value. In many ways, zaum language can be described as a poetical prefiguration of information theory's revaluation of randomness. Information theory contributed indeed to the reevaluation of randomness

9. Although we use the transliteration system ISO 9: 1995 for Russian names throughout this essay, we will use Allison Pultz and Gerald Janecek's own transcription system when quoting from their translation. 
as a positive value by differentiating between information and meaning. As Katherine Hayles explains:

[. . . ] suppose I send you the output of a random number generator. No matter how many numbers I transmit, you will be unable to continue the sequence on your own. Every number comes as a surprise; every number contains new information. By this reasoning, the more random and chaotic a message is, the more information it contains.

You may object that although the numbers are always new and surprising, they do not mean anything. The objection illustrates why it is necessary to separate information from meaning if chaotic system were to be considered rich in information. Implicit in the transvaluation of chaos is the assumption that the production of information is good in itself, independent of what it means. (Hayles 1990, 6)

Zaum poetry enacts this distinction between meaning and information by generating words not according to etymology or even homophony but according to a free play of sounds and letters as raw material. Some of the zaum words are not even sounds, but isolated letters, as if the poem were aiming at a prefiguration of computer languages, where individual letters inherit a paradigmatic value, independent from their syntagmatic value as signifiers in a chain of speech (MANOVICH 2002). Zaum language shares with computer languages both an ambition to universality and formalism, and a use of letters as algebraic units that transmit information rather than meaning.

Russian Futurist poets thought a lot about the conditions in which they could produce maximum information with minimum meaning, and they designed special techniques mixing physics-based chance procedures, misuse of literary media, and free-association in order to produce random words as meaningless as possible and as rich in information as possible. Kručenyh writes for instance of a specific technique for generating random words using Puškin's poetry as a database of random sounds. By toying with the spacing in Puškin's text, Kručenyh scrambles the original meaning of the text and produces nonsensical words (KRUČENYH 1924). Zdanevič used a different technique reminiscent of Turing's use of Machine "resistance noise" in order to produce randomness: he would begin by listening to what he refers to as "pure sounds", and then try to manipulate those sounds gradually towards existing Russian words, but without totally translating them into actual words, creating words that were half-way between words and 
noise. ${ }^{10}$ His reliance on "pure sounds" drove him to experiment with the gramophone in order to create simultaneous poetry, a poetry where up to eleven different voices would recite different zaum lines at the same time. Futurist poets were also inspired by the discovery of the psychoanalytic value of randomness. The discovery of the value of the slip of the tongue inspired those poets to channel the power of mistakes, misspellings, and misreading in order to create random poetry. In his book 17 Tools for Nonsense (Terentev [1919] 1998, 181), Russian poet Igor Terentev suggests, for instance, gathering misspellings in printed publications in order to come up with truly random words. By scrambling existing poems, folding words with sounds, shuffling different voices together, or gatherings slips of the pen, zaum poets were mixing mechanistic chance procedures and free-association. This unique mixture of avant-garde literary techniques brought forth a materiality in language far more complex than what the linguistic science of their time could formalize. Zaum poets were revealing that the stuff poetry is made of is not phonemes and morphemes, but loud sounds and print letters.

Zaum poetry led Russian Futurist poets to a revaluation of media in literature that goes beyond the scope of both Saussurian linguistic or early Russian formalism itself. For zaum poets, letters were not as much meant to be read and interpreted as they were meant to be looked at, smelled, and touched. This translated into an outstanding series of artist's books performing randomness at the level of pages and binding themselves. Kručenyh's poems with handwritten lithography by Mihail Larionov, for instance, make room for misspellings and spelling ambiguities that further randomize reading. The way the word stixotvorenija (poetry) is spelled in "Dyr bul shchyl" (illustration 1), for instance, becomes ambiguous with tvarene (jam) due to its lithographed scribbling. Spacing between letters is highly ambiguous, and it becomes impossible at times to determine whether certain groups of letters belong to one or two different words. Mihail Larionov's abstract drawings illustrating the poem resemble letters so much that it becomes challenging to distinguish between what is meant to be read and what is not. I would go as far as to say that the use of lithography and handwriting is the closest literature of this time period comes to contemporary kinetic typography where the text is in motion. Those handwritten letters are sometimes so ambiguous that they seem to bear what Katherine Hayles described as the "flickering" nature of the electronic signifier (Hay Les

10. See, for example, ZdanEvič 2001, 106. 


\section{3 cmuxaт bapenis}

каписаныя $\mathrm{Ha}$ cofcmbekon ssblkr6

Om 2p. om uiratemcr!

croba ero he unniom

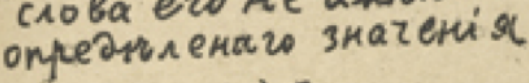

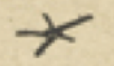

H. Dup sys useer yon $u$ us $y \mu$ ckysh bue 00 by

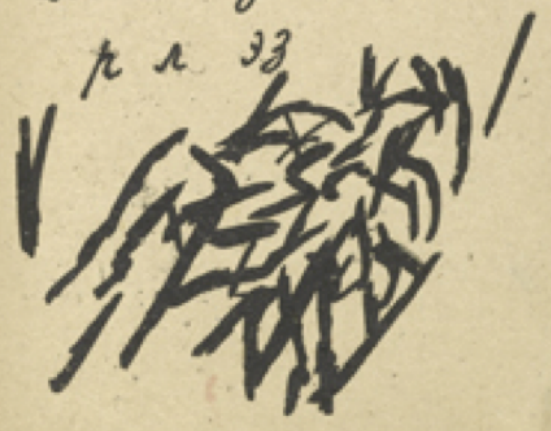

Illustration 1: KRUČENYH, Aleksej [poem] and Larionov, Mihail [lithography]. "Dyr bul shchyl". in Pomada. 1913. Digitized by The Getty Research Institute. In the online exhibit Tango With Cows. http://www getty.edu/art/exhibitions/ tango with cows/ slideshow.html.

1993). Like the flickering signifiers of electronic texts, where the original procedural nature of its core component (an alternation between 1s and 0s) instantiates in many different ways depending on the higher-level representational media through which they are interpreted, the core component of zaum poetry (lithographic traces) actualizes itself through either writing or drawing depending on the critical tools used to interpret them.

In their collective book of poetry "Transrational Boog" (illustration 2; Kručenyh and Aljagarov 1916), poets Aljagarov (a.k.a. Roman Jakobson) and Kručenyh distributed lithographed and stamped zaum poems around a set of illustrations by Olga Rozanova evoking playing cards. The book of pages becomes a hand of cards, inscribing the randomness inside the composition of the book itself. Such an ambiguity between book bind- 


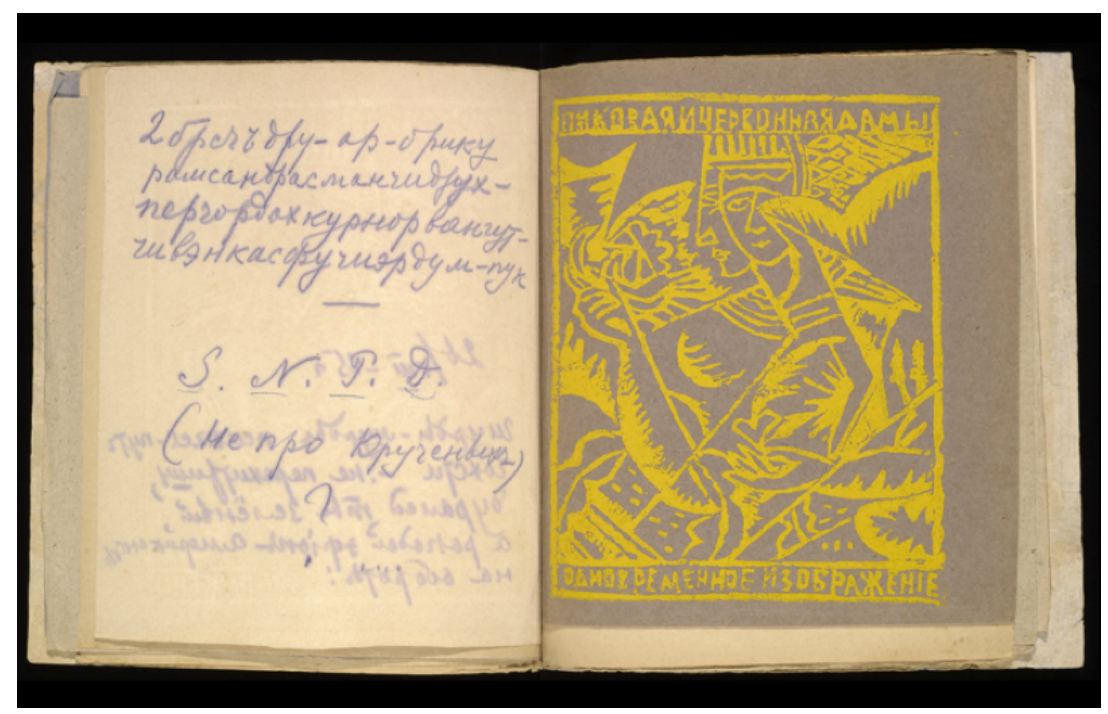

Illustration 2: KruČenyh, Aleksej and Aljagarov [aka Jakobson, Roman]. Zaumnaja Gniga. 1916. Digitized by The Gettry research institute. In the online exhibit Tango With Cows. http://www.getty.edu/art/exhibitions/tango with cows/slideshow.html.

ing and shuffling engines is epitomized in the series of hectographic ("jellygraphic") self-made books started by Kručenyh in 1918 (illustration 3). As Gerald Janecek puts it:

In these modest-looking booklets, [Kručenyh] violated nearly all the rules of Gutenbergian book production by mixing papers, haphazardly varying duplication techniques, inserting pieces of one book into another, and varying the contents and the order of the pages from one copy to another of the 'same' work. The textual components of the pages were typically treated as independent units to be shuffled at will and looked upon at least as much as visual artifacts as words to be read. (Rowell 2002, 106)

Those different misuses of media offer a seemingly unpredictable output that invites reader to look for coincidences in both the text and the book. Zaum poetry gives the book an unfamiliar function, blurring the frontier between reading and playing, and questioning the unnoticed gesture of turning the page. Recursively, the playing-cards-like free binding of 


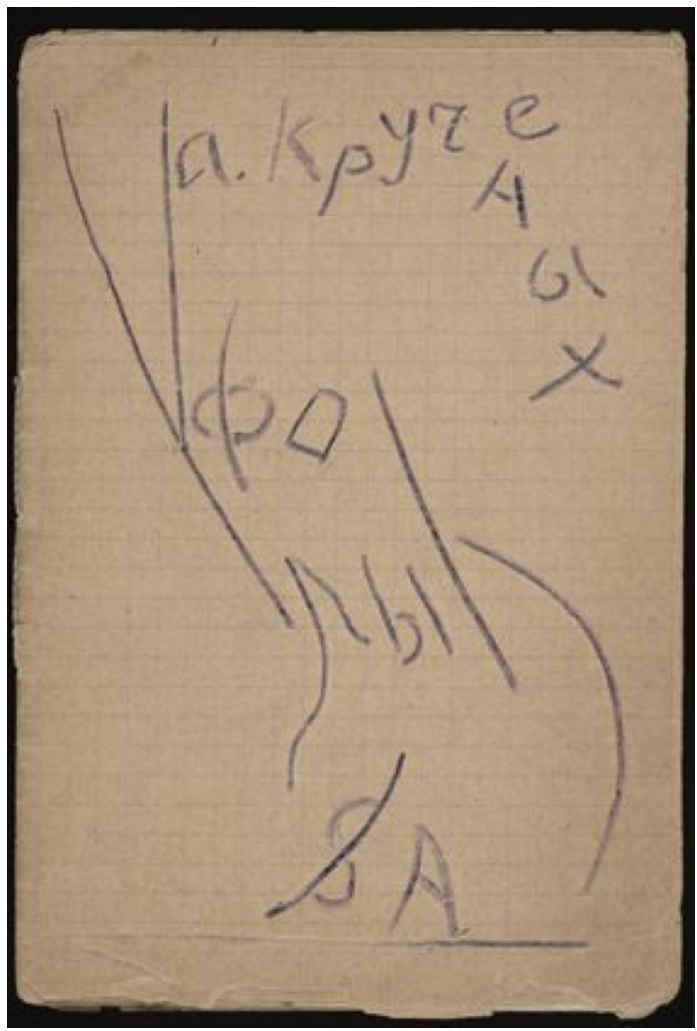

Illustration 3: KRUČENYH, Aleksej. Fo-ly-fa. 1918. digitized by the museum of modern art. http://www. moma.org $/ \mathrm{m} /$ explore/ collection/object/11326. iphone ajax.

Kručenyh's hectographic series feeds the poems with new meanings. In this complex interaction between the language of poetry and the language of printing, Kručenyh creates a feedback loop between language and media. Such misuse of the book has an uncanny effect as it creates the simulacrum of a proto-linguistic language of ink, paper, and jelly, from which would emerge complex, unpredictable interpretative and representational outcomes. Such books immerse their readers in an independent world of their own, animated by an artificial form of life.

How can a book, one wonders, give such an impression of artificial life? This question echoes a related question in this essay, which is the question of defining the conditions through which a piece of hardware can create random behaviors. A piece of generative poetry like Neil Hennessy's JABBER: The Jabberwocky Engine (illustration 4), for instance, draws on Kurt 
Schwitters' sound poems and Lewis Carroll's English neology and creates random words according to processes and with results very similar to zaum poetry. Such a piece of generative poetry combines probabilistic algorithms determining the possible output of randomly generated words within the frame of English morphology, with what are called pseudorandom number generators, algorithms that produce a series of numbers lacking any apparent pattern, and thus appearing random. Pseudorandom number generators are determined by a shorter initial value, known as a seed or key. This key is seeded from "outside" the computer. A common method to seed the computer consists in using "present time", that is, the moment when a human agent presses the button or enters the command that instantiates the program. Other methods include using the machine's resistance noise, a method invented by Turing, or using archived series of random numbers generated by third-party partners on the basis of physical phenomena such as the isotope of nuclear decay. ${ }^{11}$ Pseudorandom numbers are used to test complex systems of probability in epidemiology, meteorology, or basic programming: in order to test systems of probability, one needs to try out random scenarios. But whatever the method is, randomness is always intermediated by some form of human agency. It still belongs to human subjects to decide that nuclear decay or resistance noise or present time is random. For all we know, those phenomena could just be highly complex ones, thus appearing random to the human eye, yet totally deterministic in nature. Hayles explored in Chaos Bound different scientific approaches to chaos theory, showing that it is possible to interpret highly complex phenomena as chaotic but not necessarily random. Randomness is nothing but, at best, a scientific hypothesis, at worst, an imaginary illusion. Seeding a computational algorithm with "random" data in order to generate a series of pseudo-random numbers only performs a displacement of the basic problem of randomness, which is that it is impossible to distinguish randomness from the mere impression of complexity emerging from a set of simple deterministic rules. This ambiguity between physical characteristics and signifying strategies is epitomized in what Hayles calls the "Computational Universe". She argues that our contemporary cultural moment is marked by a deep ambiguity between computation as a means, generating or simulating reality, and computation as a metaphor for understanding natural and cultural processes (HAYLEs 2005, 4). This ambiguity causes what she calls "computation as symptom", a recursive "feedback loop" between human's signifying strategies and our common belief in such or

11. See "Randomness" in Montfort 2012. 


\section{JABBER: The Jabberwocky Engine}

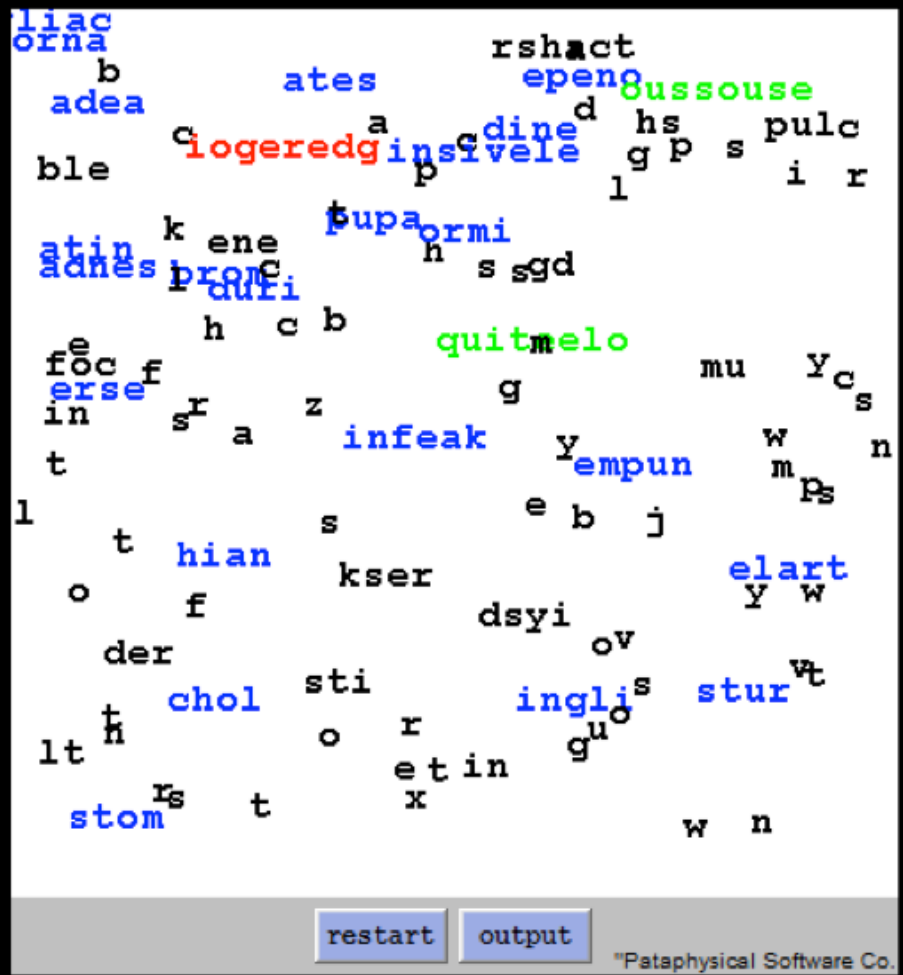

Illustration 4: Hennessy, Neil. JABBER: The Jabberwocky Engine. http://collection .eliterature.org/2/works/hennessy pataphysical/jabber/jabber/index.html.

such scientific reality as proved, generated, or simulated by computation. A very basic example is the convincing and uncanny power of robots to appear to behave according to human minds, when they simply instantiate a simple set of rules. An even more basic example is the feeling one derives from pressing down a key on a computer and thinking that the command performed by the computer is a function of the consistency of the pressure of the finger on that key. In fact, once the button is pressed down and the specific flags are triggered by this initial input, no new command is being 
performed by the program while the button is pressed down and until the button is released. Despite the fact that our finger has no positive effect on the button other than preventing the button from being released, "computation as symptom" creates a feedback loop between the reality generated by the program and our signifying strategies to interpret and embody this reality, giving us the feeling that our finger is actually "doing something" to the machine while it is pressing the button. Neil Hennessy's piece of "Pataphysical Software" JABBER: The Jabberwocky Engine performs such a symptomatic ambiguity by offering the user to click on a "Restart" button in order to provoke a new instantiation of the algorithms in charge of generating neologisms from the stirring "Soup of letters". Despite the irrefutable contingency and the limitedness of the interaction required by the poem, the user cannot but feel compelled to interpret the monstrous output as the result of his or her own genuine clicking, charging the user's gesture toward the machine with unexpected meanings.

Hayles describes this feedback loop between signifying strategies and scientific beliefs using the psychoanalytic structure of the symptom. Following Slavoj Žižek's definition of the symptom, she describes it as a "[. . .] reasoning backward from one's present position and seeing prior contingent events as constituting a necessary and inevitable teleological progression to that point" (HAy Les 2005, 219). From a psychoanalytic perspective, contingency (or randomness) is always inscribed in the dynamics of a symptomatic feedback loop between physical phenomena and human meanings by which human subjects embody reality. Sigmund Freud defines for instance the random repetition of the same number as one factor for a specific affect, the feeling of the uncanny, which is essential to the definition of symptom as repetition:

If we take another class of things, it is easy to see that there, too, it is only this factor of involuntary repetition which surrounds what would otherwise by innocent enough with an uncanny atmosphere, and forces upon us the idea of something fateful and inescapable when otherwise we should have spoken only of 'chance'. For instance, we naturally attach no importance to the event when we hand in an overcoat and get a cloakroom ticket with the number, let us say, 62; or when we find that our cabin on a ship bears that number. But the impression is altered if two such events, each in itself indifferent, happen close together-if we come across the number 62 several times in a single day, or if we begin to notice that everything which has a number - addresses, hotel rooms, compartments in railway trains - invariably has the same one, 
or at all events one which contains the same figures. We do feel this to be uncanny. And unless a man is utterly hardened and proof against the lure of superstition, he will be tempted to ascribe a secret meaning to this obstinate recurrence of a number; he will take it, perhaps, as an indication of the span of life allotted to him. (Freud 1955, 237-8). ${ }^{12}$

Freud's analysis reveals that the uncanny nature of randomness in a familiar context (unheimliche) is due to the fact that the return of the same, the same number, for instance, provokes a displaced representation of the self as a repetition of the other. Encountering twice or more the same number equates to encountering one's self as other. This encounter spurs the contradictory destructive and libidinal drives of the narcissistic complex that the subject cannot but experience when confronted with one's self as other, causing the specific feeling of the uncanny. The coincidental recurrence of a number is technically pure randomness and as such unpredictable. But after the fact, it becomes symptomatic in the sense that it functions as a channel for the narcissistic complex. There is a non-intuitive recursive temporal logic to the Freudian unconscious that enables us to claim that the unconscious is both random and deterministic. The unconscious implies determinism of thoughts and symptoms, but in order to unveil thoughts that will appear to have been determined by repressed drives, the subject needs an encounter with something random yet familiar (Unheimliche). Randomness breaks off momentarily the subject's identification with the

12. "An einer anderen Reihe von Erfahrungen erkennen wir auch mühelos, daß es nur das Moment der unbeabsichtigten Wiederholung ist, welches das sonst Harmlose unheimlich macht und uns die Idee des Verhängnisvollen, Unentrinnbaren aufdrängt, wo wir sonst nur von "Zufall” gesprochen hätten. So ist es z. B. gewiß ein gleichgültiges Erlebnis, wenn man für seine in einer Garderobe abgegebenen Kleider einen Schein mit einer gewissen Zahl - sagen wir: 62 erhält oder wenn man findet, daß die zugewiesene Schiffskabine diese Nummer trägt. Aber dieser Eindruck ändert sich, wenn beide an sich indifferenten Begebenheiten nahe aneinander rücken, so daß einem die Zahl 62 mehrmals an demselben Tage entgegentritt, und wenn man dann etwa gar die Beobachtung machen sollte, daß alles, was eine Zahlenbezeichnung trägt, Adressen, Hotelzimmer, Eisenbahnwagen u. dgl. immer wieder die nämliche Zahl wenigstens als Bestandteil, wiederbringt. Man findet das "unheimlich" und wer nicht stich- und hiebfest gegen die Versuchungen des Aberglaubens ist, wird sich geneigt finden, dieser hartnäckigen Wiederkehr der einen Zahl eine geheime Bedeutung zuzuschreiben, etwa einen Hinweis auf das ihm bestimmte Lebensalter darin zu sehen" (FREUD 1947, 250). 
signifiers that hold the self together and triggers interpretations that lead to a momentary displacement of the subject's embodiment between floating signifiers. The psychoanalytical function of slips of the tongue, dreams, and other symptoms in the psychoanalytical cure is precisely to trigger this displacement of the patient by disrupting the patient's identification with his or her most common and familiar signifiers. This doesn't mean that symptoms carry any inherent truth, or that a repository of dreams and symptoms could map a would-be collective unconscious, turning contingencies into teleological values. It simply means that the unconscious will always find a way, after the fact, to inscribe through a feedback loop what it has to say into what appear the most random in the subject's familiar signifiers.

$$
* * *
$$

In those conditions, it becomes irrelevant whether a random event is created using mechanistic random generators, as in the case of Dadaist poetry and contemporary generative poetry, or free-association, as in the case of surrealist writers and (partly) of Russian futurism. The use of computational random procedures does not exclude a rigorous definition of the unconscious if we keep in mind Hayles's concept of computation as symptom, where the unconscious is defined as an unresolved background in the interaction between the human and machine functioning. All the abovementioned methods for creating random texts thus equally introduce an element of surprise in the familiar, displacing the location of the subject's body through different signifiers and resulting indeed in very similar "literary" outcomes. What changes, though, from Dada to Futurism and from Surrealism to electronic literature, is the nature of the familiar on which the defamiliarization takes place.

The Freudian unconscious and the Computational Universe share a common notion of medium as a channel for communication that carries meaningful information, determined by language's logic, on the basis of meaningless "noise", appearing as random. In both the Freudian unconscious and the Computational Universe, media can appear nonsensical and surprising enough to trigger a moment of disruption, but is still related to language enough to produce signifying interpretations and recursive interpretations. The ambiguity of the medium, at times a form of language and something that seems to escape the logic of meaning, creates this unresolvable background that Freud called, in the context of early emerging analog and electric media, the unconscious. Pieces of both historical and electronic avant-gardes display a disruptive use of their respective media that triggers almost infinite interpretations on the basis of finite core pro- 
cedural signifiers, whether those signifiers are the alternation of $1 \mathrm{~s}$ and $0 \mathrm{~s}$ according to present time, newspapers and shuffling bags, the inscription of lithographic traces, or slips of the pen. Members of the avant-garde extract the unresolved background noise produced by their respective media and tie it symptomatically to language in order to produce excessive information and leftover meanings.

Whether using computational algorithms to create generative poetry, shuffling bags to produce Dada poetry, mixing various print techniques to craft Futurist poetry, or creating new writing protocols to generate Surrealist prose, avant-garde literature performs a misuse of our most familiar media that brings forth their respective materiality. The pushing of a button, flipping of a page, and reading down of a text can never be the same after such misuses have been performed on humans' most pervasive cultural artifacts. Literary explorations of the materiality of media do not lead to new discoveries in the functioning of either the mind or the computer. The Freudian unconscious as well as the Computational Universe remain what they are, a symptomatic frame from which one does not escape. Literary experiments with the materiality of media reveal how much subjectivity and embodiment are symptomatically rooted into everyday objects that bear imaginary representations, scientific beliefs, and physical uses. Artists remain at the foreground of the way we embody reality through media, and in that sense, are positioned ahead of both scientists and cultural analysts. As Hayles argues, what constitutes the "materiality" of literature remains a matter of interpretation. And I would add: a matter of artistry. The fact that Breton and Soupault composed Surrealist prose from free-association is no less material (that is, both contingent and symptomatically embodied) than the fact that Wylde's Storyland composes automatic writing from a computer. The unconscious has no specific site: a shuffling bag, a computer, or an ink on paper equally qualify to host symptomatic inventions.

In my comparison of literary uses of chance operations by historical avant-garde poets and uses of randomness in electronic literature, I have argued that despite the fact that randomness is context-bound and reflect different artistic agendas and scientific beliefs, mechanistically produced texts and texts generated by free-association display very similar results. This resemblance accounts for the fact that the leftover meanings produced by such texts are negotiated with readers in their encounter with the materiality of texts. Such texts, no matter how they are prepared, give randomness a positive value by which information is separated from meaning. This reevaluation of randomness enables us, for instance, to compare poetical pseudo-languages like zaum with code, in so far as such poetical "lan- 
guages" give a paradigmatic value to isolated letters and sounds that equals the algebraic use of alphabetic signs in computer languages. This characteristic use of language, exceeding linguistic and formalist definitions of speech or literature, points at the materiality of language and translates, in the case of Russian Futurism, in a mixing-in of techniques traditionally distributed among the exclusive realms of writing, printing, and binding. The misuse and hybridization of printing and literary techniques create the simulacrum of a procedural proto-language from which unpredictable outcomes emerge, offering a prefiguration of contemporary computational simulations of poetical languages. The genuine clicking of the mouse in a piece of generative poetry or the flipping of the page in a print avant-garde book are transformed by artistic cunning into an ambiguous gesture, where basic bibliographical or software components are recursively seeded back with human meanings, provoking the uncanny feeling that the inanimate is embodied. Avant-garde poetry ties symptomatically together language and media, and reveals the materiality books and computers equally bear as our most pervasive means to embody reality.

The University of Georgia

\section{Works Cited}

Breton, André. 1996. Manifeste du surréalisme. In Euvres complètes. Paris: Gallimard. Breton, André and SOUPAULT, Philippe. 1971. Les Champs Magnétiques. Paris: Gallimard.

Freud, Sigmund. 1947. Gesammelte Werke. S. Ficher Verlag. . 1955. The Standard Edition of Complete Psychological Works of Sigmund Freud. Volume XVII. Translated from the German under the general editorship of James Strachey. London: The Hogarth Press, 1955.

Getty Research institute (the). Tango With Cows. http://www.getty.edu/art/ exhibitions/tango with cows/slideshow.html.

Hayles, N. Katherine. 1990. Chaos Bound. Orderly Disorder in Contemporary Literature and Science. Ithaca: Cornell University Press.

—. 1993. "Virtual Bodies and Flickering Signifiers". October 66. http://www .english.ucla.edu/faculty/hayles/Flick.html.

. 2005. My Mother Was a Computer. Chicago: University of Chicago Press.

Hennessy, Neil. 2011. JABBER: The Jabberwocky Engine. In Electronic Literature Collection volume 2. http://collection.eliterature.org/2/works/hennessy pataphysical/ jabber/jabber/index.html.

Kittlen, A. Friedrich. 1999. Gramophone, Film, Typewriter. Translated by Geoffrey Winthrop-Young and Michael Wutz. Stanford: Stanford University Press. 
Kručenym, Aleksej. 1913. Pomada. 1913. Translated by Allison Pultz with Gerald JANECEK. http://www.getty.edu/art/exhibitions/tango with cows/slideshow.html. 1924. 500 novyh ostrot i kalamburov Puškina Sobral A. Kručënyh. http://www .bibliophika.ru/index.php?id=3522.

Manovich, Lev. 2002. The Language of New Media. http://www.manovich.net/LNM/ Manovich.pdf.

Montfort, Nick et al. 2012. 10 PRINT CHRS\$ (205.5+ RND (1)) ; : GOTO 10. Cambridge, MA: The MIT Press. http://10print.org/.

Piringer, Jörg. 2012. Konsonant. http://apps.piringer.net/.

Rowell, Margit et al.. 2002. The Russian Avant-Garde Book 1910-1934. The Museum of Modern Art.

SAmple, Mark. 2013. "An Account of Randomness in Literary Computing". http:// www.samplereality.com/2013/01/08/an-account-of-randomness-in-literary-com puting/.

Terentev, Igor. [1919] 1998. 17 Erundovyh Orudyij. Reproduced in Sobranie Sočinenie. S Francesco, 181.

Tzara, Tristan. 1920. Pour faire un poème dadaïste. In Littérature 15: 18. http://sdrc.lib uiowa.edu/dada/litterature/15/pages/18.htm.

WyLDE, Nanette. 2006. Storyland. In Electronic Literature Collection volume 1. http:// collection.eliterature.org/1/works/wylde storyland.html.

Zdanevič, Ilya. 2001. "Le Degré 41 sinapisé". In Pleine Marge 33: 106. 